\title{
Guyana Gold: A Unique Resource Curse?
}

\section{Gavin Hilson \& Tim Laing}

To cite this article: Gavin Hilson \& Tim Laing (2017) Guyana Gold: A Unique Resource Curse?, The Journal of Development Studies, 53:2, 229-248, DOI: 10.1080/00220388.2016.1160066

To link to this article: https://doi.org/10.1080/00220388.2016.1160066

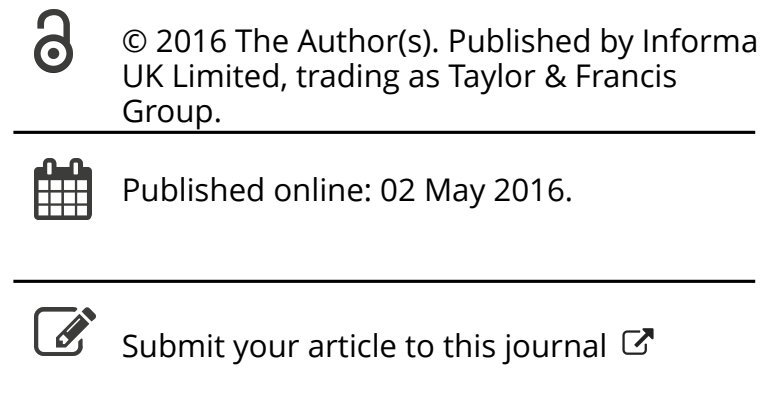

Llll Article views: 3904

Q View related articles $\widetilde{ }$

View Crossmark data \lceil

Citing articles: 11 View citing articles 


\title{
Guyana Gold: A Unique Resource Curse?
}

\author{
GAVIN HILSON* \& TIM LAING** \\ *Faculty of Business, Economics and Law, University of Surrey, Guildford, UK, **Centre for Resource Management and \\ Environmental Studies, University of the West Indies, Cavehill, Barbados
}

\begin{abstract}
This article offers explanations for the underwhelming economic performance of Guyana, a country heavily dependent on the revenue generated from gold mining. Here, government intervention has spawned a gold mining sector which today is comprised exclusively of local small and medium-scale operators. But whilst this rather unique model appears to be the ideal blueprint for facilitating local development, the country seems to be experiencing many of the same setbacks that have beset scores of other resource-rich developing world economies. Unless these problems are anticipated, properly diagnosed and appropriately tackled, a resource curse-type outcome is inevitable, irrespective of the context.
\end{abstract}

\section{Introduction}

Since the early 1990s, the 'resource curse' has received a considerable amount of coverage in the literature (Auty, 1993; Yates, 2014). Whilst the explanations given are wide-ranging, in most cases, the disappointing returns from the mining and oil and gas sectors appear to be largely a result of the particular extractive industries growth model adopted. With few exceptions, the preferred strategy for developing countries has been the 'installation' of large-scale, export-led industries reliant on injections of foreign capital and the increased involvement of multinational mining corporations. If policies are not in place which mandate these companies to invest in host countries and cultivate local skill-bases, however, there is bound to be substantial capital flight, disappointing growth, and a side-lining of local interests. This raises the question: Is there another development model capable of delivering more desirable results?

Guyana is one of few resource-rich developing countries that has opted not to pursue a large-scale, exportled extractives blueprint. The Government of Guyana has, for more than three decades, rather emphasised creating the necessary policy conditions for local gold miners to flourish. Today, the country's gold mining economy is populated exclusively by Guyanese-owed small and medium-scale operators financed predominantly by local investors. This strategy has proved extremely successful economically: the sector has experienced significant growth, and now produces in excess of US\$300 million in gold annually.

This article reflects critically on the Government of Guyana's decision to promote and develop a gold mining sector comprised exclusively of local small- and medium-scale operators. Has this strategy catapulted the country on to a development trajectory that has proved so elusive in countless other extractive industries-based economies, and perhaps more importantly, helped it to avoid the many pitfalls of resource dependency? The results thus far are not particularly encouraging. Whilst a domestically-owned industry offers great potential for promoting local economic development, as the

Correspondence Address: Gavin Hilson, Faculty of Business, Economics and Law, University of Surrey, Guildford, GU2 7XH, UK. Email: g.m.hilson@surrey.ac.uk

Present address for Tim Laing is Centre for Resource Management and Environmental Studies, University of the West Indies, Cavehill, Barbados. 
case of Guyana shows, it is not a sufficient precondition, in the absence of suitable institutions, to facilitate this.

\section{The Resource Curse: Searching for Explanations}

Why are so many natural resource-rich developing countries performing so poorly economically? The bulk of analysis undertaken to date has sought to identify common patterns and trends. But efforts to find common ground and sets of variables have confirmed precisely the opposite: that the way in which what is defined as a 'resource curse' typically manifests depends on the policy context, geographical setting as well as geological attributes (see Ross, 2014). It has become abundantly clear that there is no single all-encompassing explanation for the resource curse.

There do, however, appear to be some common explanations for underperformance among certain resource producers. In the case of gold-rich developing countries, this could in part be explained by the development path selected. Specifically, the blueprint being followed in the likes of Papua New Guinea, The Philippines, Ghana and Peru, where gold mining is now the dominant industry, prioritises export-led, large-scale extraction and processing. A commitment to this strategy, however, has not delivered anywhere close to the level of socioeconomic development projected.

The discussion that follows briefly examines the major 'strands' of the resource curse, as highlighted in the literature, in gold-rich economies, in the process framing the analysis of the Guyana case that follows.

\subsection{Resource Enclavity and Dutch Disease in Gold-Rich Developing Countries}

Continuous demand for gold in the jewellery and the electronics industries, as well as for investment (it being one of the most tradable commodities in the world), has fuelled mine production worldwide. Many developing countries have been advised by donors to open up their gold mining industries to foreign investment which, they maintain, could provide a much-needed catalyst for economic growth. The series of tax breaks and generous investment incentives now offered by a range of developing countries have, over the past two decades, attracted numerous foreign gold mining and mineral exploration companies to their shores. But whilst successfully facilitating an impressive expansion of large-scale gold mining worldwide, the developmental 'returns' from this growth have been underwhelming on the whole and, at times, invisible. How have scholars explained this paradox?

An initial observation concerns the brand of development being promoted. Specifically, the 'booming' projects which investment incentives have spawned are not particularly well-positioned to facilitate local economic development in the ways in which donors often predict. Most have taken the form of what Ferguson (2005, 2006), Ackah-Baidoo (2012) and others refer to as 'resource enclaves'. Using Africa's oil industry as a reference point, this body of scholarship argues, quite persuasively, that these 'booming' pockets develop in relative isolation:

When capital is invested in spatially segregated mineral-extraction enclaves, the 'flow' of capital does not cover the globe, it connects discrete points on it ... What is noteworthy is the extent to which this economic investment has been concentrated in secured enclaves, often with little or no economic benefit to the wider society ... Capital does not 'flow' from London to Cabinda; it hops, neatly skipping over most of what lies in between. (Ferguson, 2005, pp. 378-380)

The ability of a country such as Mali to maintain high levels of gold production - and in the case of some mines, increase output - in the middle of a civil war is a telling sign of how fortified and isolated large-scale gold mining enclaves can be. ${ }^{1}$

As indicated, Guyana is one of few developing countries that has not followed this path. Whether a slowness at detaching itself from the ideologies of the socialist dictator Forbes Burnham, a reluctance to encourage industrial mining because of past negative experiences, or simply not seeing the merit of 
the particular developmental blueprint overall, the government has been quite pedestrian with promoting export-led, large-scale gold extraction. In fact, Canadian-owned Guyana Goldfields Inc.'s Aurora mine, which began production in 2015, was the country's first large-scale gold project in nearly two decades.

Perhaps part of the reluctance of Guyana to follow the lead of, say, Ghana or Peru, is attributed to the inability of these, and other gold-rich countries that have promoted export-led, large-scale mining, to produce an extractives-based sector with linkages to other industries. Early analyses of these issues provided an important foundation for what is commonly referred to in the literature as 'Dutch Disease', defined as 'changes in the structure of production that are predicted to occur in the wake of a favourable shock, such as discovery of a large natural resource or a rise in the international price of an exportable commodity that is perceived to be permanent' (Brahmbhatt, Canuto, \& Vostroknutova, 2010, p. 1).

It was Prebisch (1950) and Singer (1950) who, in reflecting on an extended period of colonialism, first broached the idea of 'core' and 'periphery' in the context of primary industries and development. The former argued, in a report published on behalf of the United Nations, that 'the outstanding differences between the standards of living of the masses of the former [developed countries] and the latter [developing countries] are due to the manifest discrepancies between their respective abilities to accumulate capital, since the margin of saving depends primarily on increased productivity' (p. 1). The latter voiced similar concerns, hinting that resource enclaves in developing countries are largely a façade because 'the productive facilities for producing export goods [in underdeveloped countries] are often foreign owned as a result of previous investment in these countries' (p. 474). Hirschman (1958) built on this analysis, exploring economic development through a series of linkages.

A series of critiques (for example, Bloch \& Owusu, 2012; Morris, Kaplinsky, \& Kaplan, 2012) have emerged in recent years which challenge the 'enclave thesis', but most are unconvincing. To champion this position would be to deny that the very objective of the revised laws and policies implemented across sub-Saharan Africa, Asia and Latin America is to encourage foreign investment in extractive industries in the first place. In fact, it is difficult to see how the series of tax breaks and incentives offered would not fuel resource enclavity. The proliferation of efforts being made across the developing world to coerce companies into 'thinking' more constructively about, and more importantly contributing more to local economic development can, from a certain point of view, be interpreted as a deliberate move to tackle enclavity (Ovadia, 2014; World Bank, 2013).

Perhaps the most significant problem with the blueprint being followed is that it has spawned what appears to be Dutch Disease. The vast majority of gold-rich developing countries continue to lag at the bottom of the UN Human Development Index and are becoming even more dependent on the industry for their sustenance. A host of in-depth empirical analyses (for example, Corden, 1984; Heinrich, 2011) have emerged over the years which seem to reinforce this, each drawing attention to how a resource allocation effect and/or spending effect have nourished the 'booming' sector - in this case, gold mining - whilst simultaneously inhibiting the growth of other industries, in particular manufacturing and agriculture. These phenomena are certainly more pronounced in petro states such as Angola, Venezuela and Nigeria, where an emphasis on oil production has yielded some of the most one-dimensional economies in the world. But many gold-rich developing countries which have embraced the large-scale mining, export-led growth blueprint do not seem to be too far behind.

For example, and as highlighted by the World Bank (World Bank, 2009), Ghana, which has long been a top-10 gold producer, 'has not developed a competitive manufacturing sector' (p. 45). During the period 2000-2006, it ranked 30 out of 42 countries in sub-Saharan Africa on the rate of growth of total exports, largely because it is ill-equipped to fabricate goods: its firms have less machinery and equipment per worker (US\$1200) than those in most other countries in the region; less than one quarter of its manufacturing firms export; and its labour productivity (US\$1000) is extremely low, approximately one sixth that of China, Kenya and Swaziland. Papua New Guinea seems to have experienced much of the same. The value of the country's kina, which is often described as a 'commodity currency' (Mahadevan \& Asafu-Adjaye, 2013), has appreciated to the point where manufacturing is no longer competitive, a situation brought about by undisciplined policymaking 
during the country's most recent mining boom (1991-1993) as well as an acute shortage of skilled workers. Consequently, manufacturing output has declined by almost 3 per cent over the past decade, as has its contribution to GDP (Avalos, Gonzales, Stuva, Lida, \& Okazoe, 2013). Even 'new frontiers' such as Mongolia seem to be experiencing 'Dutch Disease'. ${ }^{2}$ Here, a recent mining boom, at the heart of which is large-scale gold extraction, has led to the awarding of prospecting and extraction licenses which cover an estimated 43 per cent of the country's territory (USAID, 2010), and has sparked fresh concerns over the future of agriculture, long the country's staple industry (Moran, 2013).

For various reasons, Guyana has managed to steer away from developing a gold mining economy built on financial injections from foreign multinationals and accompanying large-scale activity. But in doing so, has it managed to avoid Dutch Disease?

\subsection{Institutions and Corruption}

Persistent Dutch Disease and enclavity raise the question of why, despite the disappointing results to date, governments continue to promote export-led, large-scale gold mining, in the process preserving the necessary conditions for these problems to persist. The fact that governments can seize rents more effectively from large-scale operations versus the dispersed myriad groups of small operators may contribute somewhat towards this policy preference. Weak institutions and corruption - what Hilson and Maconachie (2009) refer to as the 'institutional strand' of the resource curse - go a long way toward explaining why: that governments, at times assuming power illegitimately, cannot be held accountable for their actions by a marginalised public. Without effective scrutiny from the citizenry, and few checks and balances in place, it is not surprising that little has been done to ensure that rents from activities are managed prudently.

The 'institutional strand', or the unwillingness of politicians to use rents for development, has long been a feature of the resource curse debate. It is difficult to pinpoint when, exactly, the issue was first broached but the landmark study by Sachs and Warner (1995), which explored 'a negative relationship' between resource abundance and economic growth, along with seminal works by Auty (1991, 1993) and Karl (1997), seemed to spark more vibrant and innovative discussion in this area. Analysis of this strand of the resource curse has since been advanced by a host of quantitative studies, which use various (institutional) data to identify potential links between resource wealth and governance (for example, Ahmadov, 2014; Bergh, Mirkina, \& Nilsson, 2014), as well as detailed qualitative assessments of the performance of institutions in individual countries such as Angola (Amundsen, 2014; Saka \& Sani, 2012), Nigeria (Sala-i-Martin \& Subramanian, 2013; San, 2014), Venezuela (Mähler, 2011; Mazzuca, 2013) and Chad (Gould \& Winters, 2007).

It was two decades ago that Sachs and Warner (1995), reflecting on how observations made over the centuries apply to the extractive industries of the present, proposed that 'easy riches lead to sloth' (p. 4) and Lane and Turnell (1996) observed that, on the whole, rent-seeking behaviour is most widespread in countries with low-quality institutions. Perhaps the most illustrative examples of how windfalls and influxes of rents stifle creativity and proactivity at the policymaking level are oil richdeveloping states, many of which are run by dictators who use finances to enrich themselves and their patronage networks. The concern, as witnessed in countries such as Angola and Gabon (Shaxson, 2009), is that governments tax companies, not people; at times, they do not tax at all (Ross, 1999, 2001). With taxation being the foundation of accountability between the state and its citizens, a commitment to doing so has the potential to bolster the legitimacy of governments, stimulate institution-building, and enhance democracy (Bräutigam, 2008; Moss, 2011). Deliberate moves taken to stop taxing the citizenry, therefore, create a wider divide between the public and the government.

The main concern in gold-rich developing countries is the potential for the misappropriation of royalties and taxes. There is growing public frustration over spending, in all likelihood the result of international efforts to increase traceability. At the top of this list is the Extractive Industries Transparency Initiative (EITI), ${ }^{3}$ which has drawn attention to the dynamics of revenue flows and the quantity of monies changing hands. The amounts are indeed considerable. For example, in 2011, 
the Government of Peru collected US\$646 million in taxes from mining, along with 30 per cent income tax payments from individual companies, ${ }^{4}$ and Ghana received US\$500 million as a collective contribution from resident operators. ${ }^{5}$

Rosser (2006) has put the debate into perspective, drawing attention to how the resource curse has largely been explored in economic terms, with very little attention paid to issues such as governance and institutions, despite there being 'a consensus [that] is emerging that various political and social variables mediate the relationship between natural resource wealth and development outcomes' (p. 3). Behaviour and actions - or elements such as 'sloth' and corruption that have come to embody the 'institutional strand' - certainly go a long way toward explaining the resource curse. Increased coverage of the subject has also provided ample ammunition for those who have challenged the idea, many of whom believe that a 'paradox of plenty' is not inevitable but rather that the inability of developing countries to harness their natural resource wealth is linked purely to corruption and a lack of governance.

To reiterate points raised at the beginning of this section, it is becoming abundantly clear that the underwhelming performance of most resource-rich developing countries is due to a number of interrelated factors; some of these 'strands' are more prominent than others in certain settings. Moreover, and as will be shown in the case of Guyana, similar outcomes can arise even if an entirely different developmental blueprint is pursued altogether.

\section{Critical Reflections on the Resource Curse in Guyana: Different Economic Strategy, Same Results?}

As is the case with countless other developing countries, Guyana is over-dependent, economically, on gold mining. But as mentioned repeatedly thus far, the sector is unique in its composition: Guyana has deftly avoided pursuing the extractives model in place elsewhere, electing rather to prioritise the development of a gold mining industry comprised of indigenous small- and medium-scale operators. On paper, the promotion and empowerment of the Guyanese operator backed by local finance, who has greater links to local communities than any foreign miner, and with presumably more of an interest in ensuring that a greater share of benefits from activities are captured locally, is undoubtedly a more viable blueprint for local extractives-led development than the more popular large-scale, export-led model. As Hennessy (2015) explains, today, the sector's assortment of small- and medium-scale operations collectively supports as many as 100,000 people (12\% of the population), helping to 'buffer against the austerities of structural adjustment, an unreliable labour market and wage-based work' (p. 134). Guyana's 1989 Mining Act has facilitated an explosion of activity: two million acres are now covered by small-scale permits alone (Figure 1).

But a 'home-grown' gold mining industry has failed to shield Guyana from a resource curse. The analysis that follows examines the major 'strands' of the phenomenon, drawing upon selected quantitative data and findings from interviews conducted in-country over two periods of fieldwork between March and September 2013. During the first phase, interviews were conducted with major stakeholders in Georgetown, including policymakers from the Guyana Geology and Mines Commission (GGMC), The Guyana Gold Board, the Guyana Rice Development Board and the Guyana Forestry Commission; officers from Amerindian groups; and officials from the Guyana Gold and Diamond Miners Association (GGDMA). During the second phase, interviews were conducted with key actors at the community level, beginning in Mahdia, one of Guyana's main gold mining communities, in an effort to provide a clearer picture of the situation in the industry. Here, 50 miners (all major permit holders) were interviewed, along with local government staff. Following this, visits were made to rice and sugar estates to gain a broader understanding of how gold mining has affected Guyana's 'other' industries. In total, interviews were conducted with four rice farmers on Leguan Island, four sugar estate managers in Demerara, and four sugar estate managers in Berbice. ${ }^{6}$ 


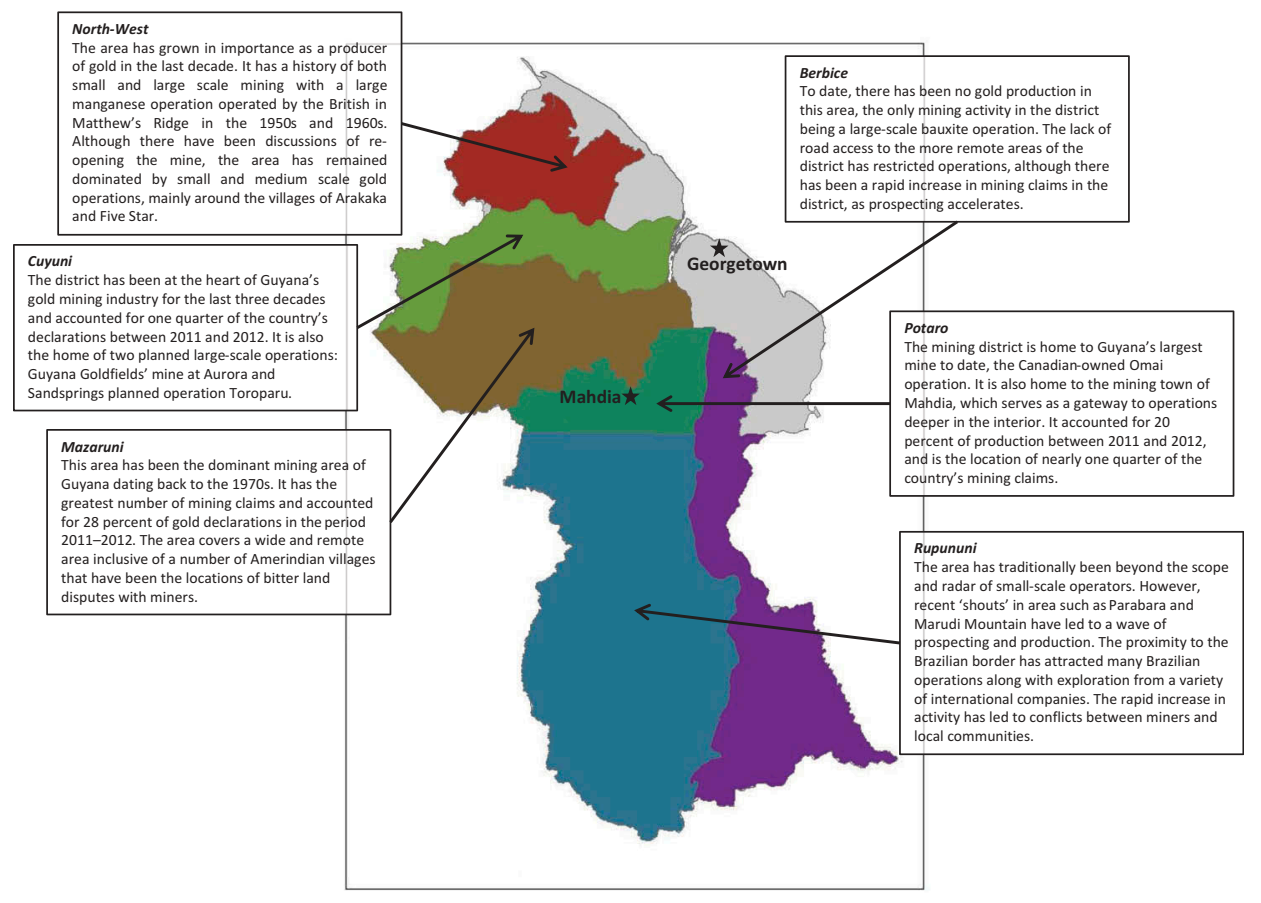

Figure 1. An overview of Guyana's main gold mining regions.

The reasons behind the country's underperformance seem to mirror those described in critiques of other resource-rich developing countries.

\subsection{Dutch Disease in Guyana: A New Strain?}

What proponents of the resource curse refer to as 'Dutch Disease' appears to be deeply-rooted in Guyana. Its origins can be traced back to the country's colonial period, during which time the population expanded on the back of a growing sugar industry developed by the British Empire. For over a century, Guyana has struggled to diversify its economy due to a combination of postemancipation labour and land distribution policies (Da Costa, 2007). Of the little diversification that has occurred to date, most is owed to the tireless efforts of subsistence Guyanese families who, facing very difficult circumstances, were forced to turn to alternative economic activities, such as rice farming and gold mining. Not surprisingly, these people have developed strong cultural ties to these industries.

Today, Guyana's economy remains highly dependent on the exports from this small group of industries: sugar, rice and gold, as well as timber and bauxite. Between 1991 and 2004, these accounted for 75-80 per cent of exports (Staritz, Gold, \& Atoyan, 2007), and reached almost 90 per cent in 2012 (Guyana Bureau of Statistics, 2014). Gold mining, however, has since rapidly emerged as the country's principal industry. Despite a fall in the world market price for gold, in 2013, Guyana recorded its highest level of production, at 458,105 oz, up from 438,645 oz in 2012 and 363,083 oz in 2011. ${ }^{7}$ This was made possible by the unprecedented increase in the number of small- and mediumscale miners. Between 2005 and 2011, there was nearly a 50 per cent increase in the number of smallscale permits (nearly 15,000) issued by the government; and, at the time of writing, there were more than 12,000 registered dredges. Between 2007 and 2011, revenue from the sector increased 30 per cent annually, from US\$170 million to more than US\$570 million (Germany Trade and Invest, 2013). These impressive results were due to a combination of an attractive gold price, an increased 
availability in the number of mining properties, and improvements in technologies and practices (ECLAC, 2014; Singh et al., 2013).

Buoyed by this booming gold mining sector and, to some extent, rice production, Guyana's economy continued to expand in 2013, growing by 5.2 per cent (Economic Commission for Latin America and the Caribbean (ECLAC), 2014), up from a 5 per cent average between 2009 and 2013 and only 2 per cent annually between 2000 and 2008. But this impressive growth, facilitated largely by a uniquely-structured mining sector, has overshadowed a number of systemic economic problems and ultimately, has failed to prevent the onset of Dutch Disease. There is, first and foremost, the state of domestic manufacturing, which, apart from paddy and rice milling, and molasses production from sugar, is virtually non-existent. The vast majority of intermediate capital goods required for industries such as construction, agriculture and mining, therefore, must be imported. The stable macroeconomic growth of Guyana over the last 15 years has fuelled an increase in the imports of goods such as machinery and tractors, with the total import of these intermediate capital goods rising by 10 per cent annually during the period 1999-2013 (Guyana Bureau of Statistics, 2014).

This growth, however, has been outstripped by the rise in imports of capital goods for mining. Specifically, escalated demand for excavators, new engines and pumps stimulated an increase in the imports of these capital goods: 55 per cent between 1999 and 2013, and reaching a height of 127 per cent annually between 2008 and 2013, the peak of the international gold price (Guyana Bureau of Statistics, 2014). The scale of this growth in imports has led to the importation of mine machinery becoming big business in Guyana. It has grown from a mere sliver of total imports 15 years ago to a sizable portion today (Figure 2), in the process diverting finance from other industries. The rapid movement and reallocation of various factors of production to small- and medium-scale gold mining has led to the relative, and in some cases, absolute, decline of previously-key economic sectors. As short a time ago as 2006, gold mining accounted for as little as 5 per cent of GDP at current prices, but a boom in international prices and simultaneous rise in production caused it to soar to over 17 per cent by 2012 (Guyana Bureau of Statistics, 2014). This increasing dominance of gold was mirrored by a decline in performance of other key exporting sectors. For example, during the same period, manufacturing stagnated and slowly declined from 7.5 to 6.5 per cent of GDP.

A second significant development has been the stagnation of agriculture, again, another welldocumented 'symptom' of Dutch Disease. The sugar industry, long integral to the cultural identity

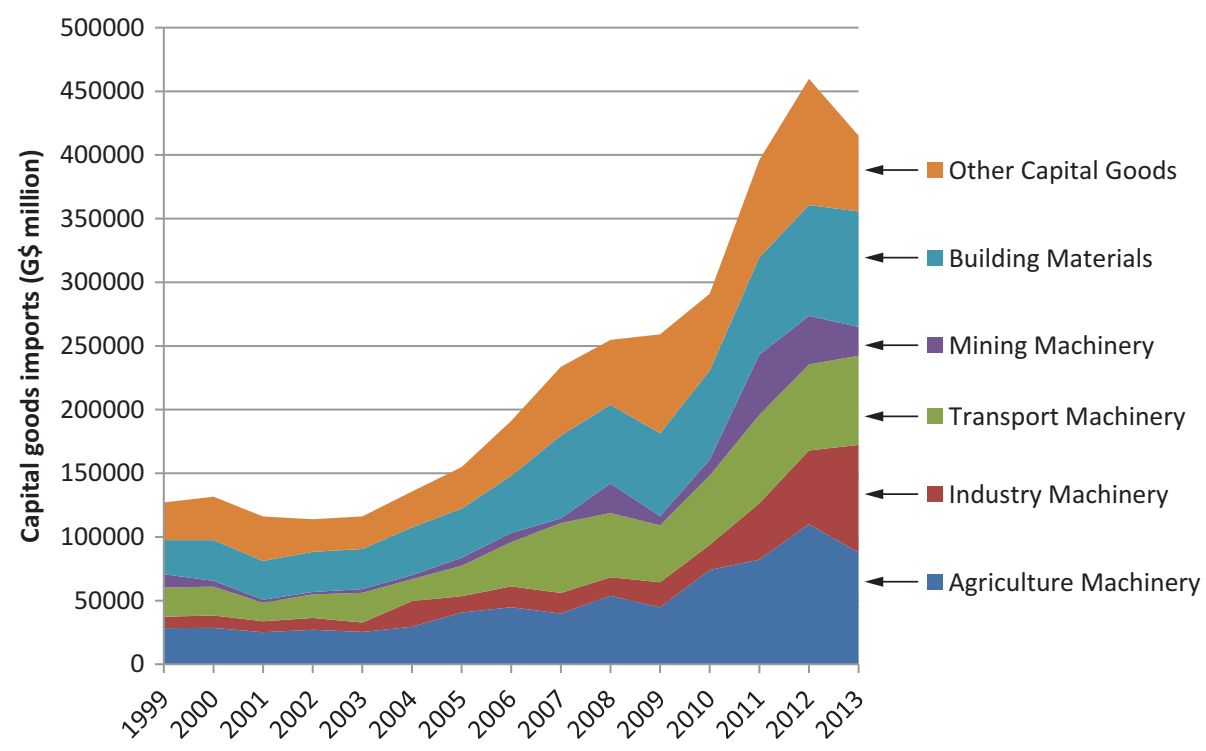

Figure 2. Imports of capital goods to Guyana, 1999-2014. Source: Guyana Bureau of Statistics (2014) 
of Guyana, has virtually collapsed, today contributing less than 4 per cent of GDP, down from over 7 per cent in 2006. Guyana was a primary beneficiary of the Sugar Protocol, annexed in the Lomé Convention of 1975 that committed the European Economic Community to buy $0.16 \mathrm{Mt}$ of raw sugar, at negotiated prices from the country annually (Richardson-Ngwenya, 2013). The Sugar Protocol, however, was officially dissolved by the European Union in 2007 on the grounds that it was believed to be incompatible with fresh WTO commitments. It was subsequently replaced in 2008 by an Economic Partnership Agreement - duty-free, quota-free access but with no guarantees on prices or market share. Failure to anticipate this course of action and to develop alternative export markets for its raw sugar during the time of the Sugar Protocol, however, has contributed to the rapid decline of Guyana's flagship industry.

In addition, there are the extremely misleading 'gains' from rice farming in recent years. The product of the resistance and skilful diversification of indentured sugar state workers during the colonial period, Guyana's 'second' agricultural industry has rapidly grown over the past 100 years, initially servicing domestic needs and subsequently those of neighbouring Caribbean destinations with sizable East Indian populations (Potter, 1998). The rice farmers interviewed seemed convinced that the industry is viable, even during a gold boom. One went as far to suggest that today, even the industry's general labourers could lead a prosperous life:

A man can even work as a labourer GU\$3000/day and he wife don't have to work. At GUY $\$ 4000 /$ day, you can take a mortgage of three million, pay off he house and still live comfortably, paying GUY\$20,000/month. This man here take a mortgage for two million, and he build he house, he wife not working, [and] he living comfortably. ${ }^{8}$

Whilst this may be the case at present, the recent sharp rise in rice production is owed largely to a PetroCaribe rice-for-fuel deal forged with neighbouring oil-rich Venezuela. ${ }^{9}$ The agreement, which at the time of writing, provided Guyana with a valuable guaranteed market for a large percentage (around two-thirds) of its rice production, ${ }^{10}$ has sustained the industry in the short term. This, however, was a random and somewhat unanticipated development, and nothing to do with the acumen of a government looking to identify viable export markets for its agricultural industries. It was rather an agreement reached with a neighbouring country, Venezuela, which - rather ironically - is also suffering from Dutch Disease, to the point where it is similarly deemphasising the production of staples and willing to subsist off of the trading power commanded by its natural resource wealth, in this case, petroleum. As Jacome (2011) explains, in 2009 and 2010, Guyana's debt to PetroCaribe was US\$143 million and US $\$ 180$ million, respectively. Under the agreement, Guyana exports substantial supplies of rice $(143,081$ $\mathrm{mt}$ in 2012) in exchange for 5200 barrels of oil daily (Economic Commission for Latin America and the Caribbean (ECLAC), 2014; US Rice Producers Association, 2011). But how sustainable is this arrangement? As with sugar, a sudden change in Venezuela's economic strategy could spark a radical reorientation, and consequent crash, of Guyana's rice market. These concerns have been magnified by the current unrest and economic crisis in Venezuela, and the recent rapid decline in the global oil price. ${ }^{11}$ In mid-2015, the agreement had been put on hold. Although these effects lay largely outside of the traditional model of Dutch Disease, they nevertheless highlight the potential pitfalls of the dependence of an economy on a single natural resource sector and 'preferential trade-protected' agriculture.

A final 'symptom' of Dutch Disease is the marked increase in services for the booming resources sector. In addition to the rapid surfacing of equipment distributors and shops, financial services are now readily available for gold mining. This has been a significant development because the industry's operators have traditionally struggled to access credit, a lack of collateral, uncertain profits and the risks with operating in remote environments forcing most to finance their own activities. But local lenders are now more flexible when it comes to lending to miners.

The scale of the increase in capital flowing to gold mining can be seen in Figure 3. In 2004, the sector accounted for just 1 per cent of total commercial bank loans but this grew to nearly 6 per cent by 2014 (Central Bank of Guyana, 2014). The construction, as well as the wholesale and retail 


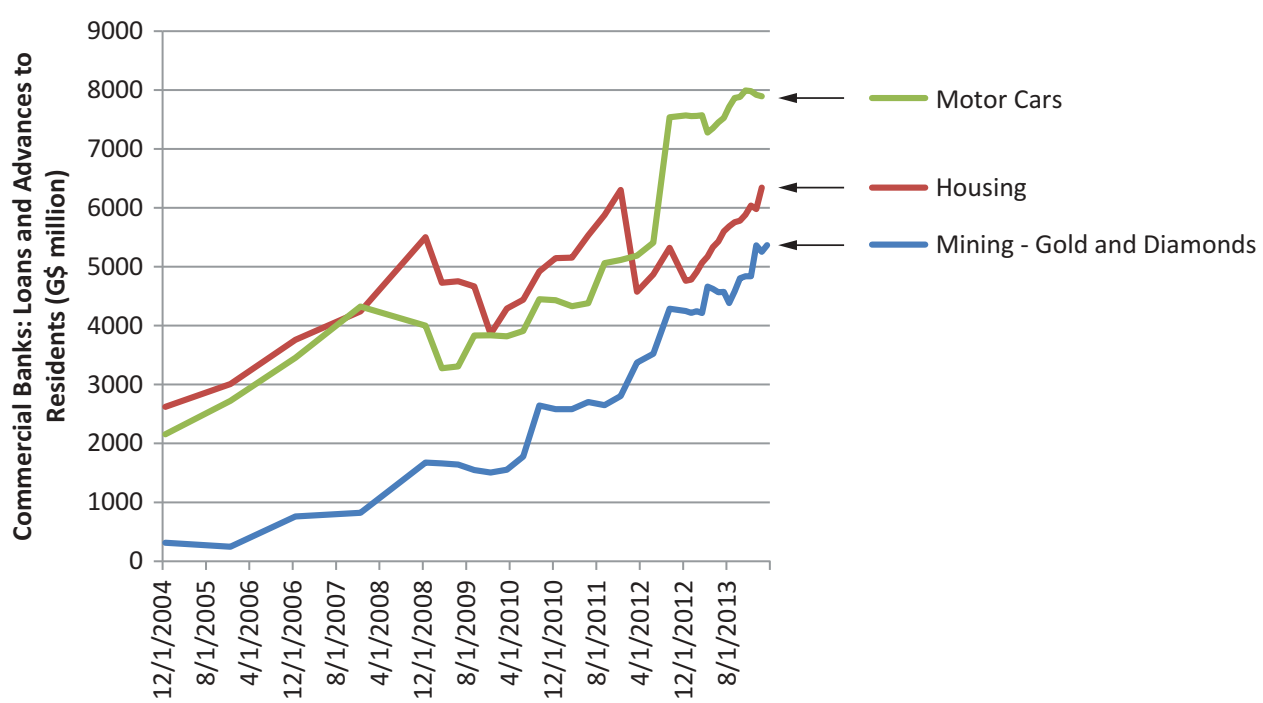

Figure 3. Commercial bank loans and advances to residents in the mining sector as a percentage of total lending to business enterprises.

Source: Central Bank of Guyana (2014)

industries have also grown rapidly on the back of small and medium-scale gold mining. The increased disposable incomes of those employed directly in mining, along with those providing support services, has fuelled a construction and property boom and escalated demand for consumer products in the country capital, Georgetown. Evidence of this surge can be seen in the rapid expansion of credit made available to Guyanese residents for housing and motor cars. Total lending to households grew at nearly 20 per cent annually between 2004 and 2014, with loans for motor cars, often backed by deposits secured in gold mining, growing by 26 per cent annually (Figure 4). This shifting of capital from productive investment in industry and agriculture towards consumption is further evidence of the diverting effect of a natural resource boom. In fact, a domestically-owned mining sector may be more prone to this, as rents are converted into expanded domestic credit for consumption. The credit boom

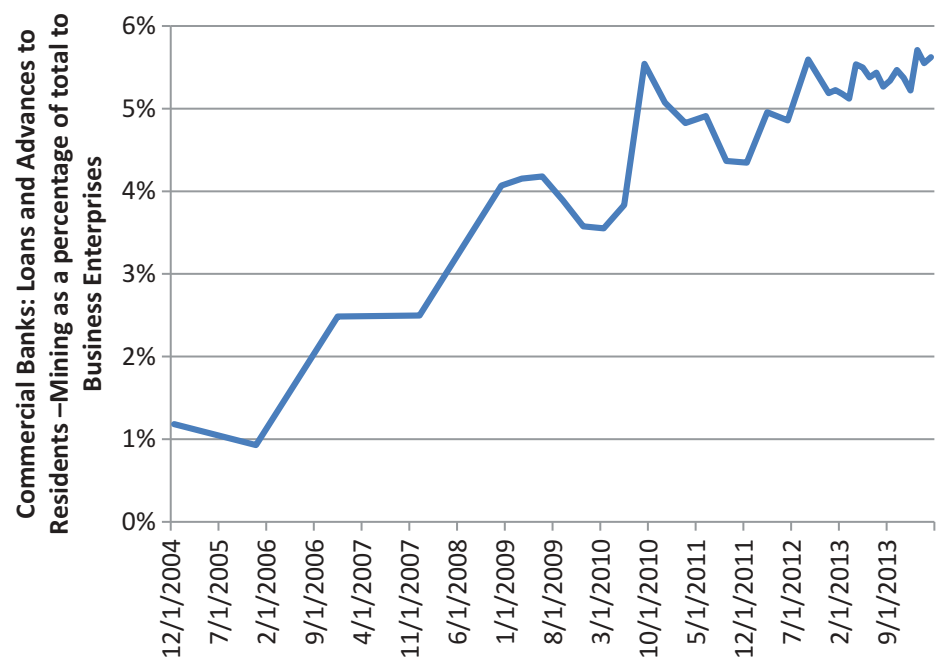

Figure 4. Commercial bank loans and advance to residents: mining, housing and motor cars, 2004-2013. Source: Central Bank of Guyana (2014) 
has helped to increase living standards but the full consequences of such a diversion from productive investment will only be felt at the conclusion of the resource boom, when many may face problems repaying this credit. This is a different dynamic from traditional Dutch Disease but may be an additional symptom of a dependence on one commodity coupled with a lack of long-term contingency planning.

Why has Guyana become so dependent on small and medium-scale mining and in the process, suffered from what many scholars would consider 'Dutch Disease'? Because of its lack of large deepsea port facilities, limited air transport and a high cost, intermittent energy system, the country is not well-positioned to diversify. There is also the perpetual political tension between Afro and IndoGuyanese, which proved significant enough to stifle efforts to promote a manufacturing sector, through credit and tax incentives, in the 1950s (Da Costa, 2007; Staritz et al., 2007). Given these constraints and the formidable challenges faced in addressing them, if the government is, indeed, committed to bringing Dutch Disease under control, it must be prepared to implement innovative development strategies.

\subsection{Labour Movements}

In Guyana, the 'resource movement effect', a phenomenon first articulated by Corden (1984), is perhaps best exemplified by the mass migration of labour from sectors such as agriculture to gold mining. Guyana's struggles to retain skilled people could explain why the government has not been particularly proactive in controlling this movement of labour: at the turn of the century, it was reported that the country, which was losing over 70 per cent of its citizens with a tertiary education to the United States, had the highest 'brain drain' in Latin America and the Caribbean (Carrington \& Detragiache, 1999). The country lost around 1 per cent of its population every year between 2000 and 2012 to just the United States (United States Department of Homeland Security, 2009, 2012). But emigrants seem to be returning to Guyana, en masse, strictly to engage in gold mining. This may explain why the government, grateful for a replenishing of the population, has chosen not to take action to reduce the simultaneous flows of labour from agriculture into mining. The initial argument made by Corden (1984) was that the capital-intensiveness of the extractive industries and their low demand for labour often make the scale of this movement negligible. But this has not been the case in Guyana's gold mining sector because, again, of its rather unique composition - specifically, it being composed of solely labour-intensive and semi-mechanised small- and medium-scale activities. Flows of people into the country's interior, therefore, have been significant: whilst official data are sparse, the GGMC reports that labour in the mining sector grew by 16 per cent between 2008 and 2010 (GGMC, $2009,2010,2011$ ) and today, accounts for over 10 per cent of the workforce.

Although some of this excess labour has been drawn from Guyana's predominantly urban-based unemployed, most has come from rural agricultural communities, which are populated with people whose skills and lifestyle are more suited for undertaking the work required in the 'gold bush'. Rice and sugar have been hit the hardest, their rapidly-changing labour dynamics in many ways reinforcing scholars' predictions concerning countries affected by Dutch Disease. In Guyana, a 'booming' smalland medium-scale gold mining sector offers attractive wages and remuneration packages, which have lured people from rice and sugar. Throughout the country's protracted gold boom, these industries struggled mightily to maintain an adequate supply of general labour. In the former, according to one senior government official, 'what we [now] have is a labour shortage':

The gold price [is] having an effect because the high price the gold miner pays for the worker, [and] the former [that is, rice] cannot ... Gold mining industry pull a lot of people and spoil them, and they can't work for that [wage] anymore ... You get GUY\$800,000 in the bush but GUY $\$ 200,000$ in farming, so we can't compete... ${ }^{12}$

One rice farmer reflected on the situation at great length in an interview, explaining that 'after the gold price rose, they [the workers] givin' up [and so] labour gone, milling gone down, so production 
dipped'. ${ }^{13}$ The same government official clarified that only when 'the gold price is down, [do] you get people on your [rice] farm'.

Such erratic work patterns would normally not be regarded as acceptable by any employer but the situation is now so bleak in the sugar sector that estate managers welcome back labourers who leave unannounced and even tolerate people not showing up for work. One estate manager interviewed in Berbice $^{14}$ acknowledged that, since 2005, attendance has been 'a problem' and that many people 'don't work all days required'. The manager explained that the peoples' pursuit of work, unannounced, at gold mines for weeks and sometimes months at a time has left the estate's labour force at ' 70 per cent attendance', which is very close to the 60 per cent needed 'to keep the factory going'. The situation is even more precarious in Demerara, which, being the industry's closest 'door to the interior', where jobs in gold mining are in abundance, is struggling much more than estates in Berbice. A government official reflected on the very difficult and unpredictable situation in Demerara:

Operators don't return to work and you subsequently find out when you inquire. You don't see them for a couple of weeks and you find they go to mining ... But because we don't have the people, so they come back and tell you a story and you take them back because you don't have the people. ${ }^{15}$

Another estate manager explained that 'we are badly short of labour - we run two 12 hour shifts but when they [the workers] get paid on Friday, they go drink but they don't show up for the weekend [work] but because of shortage of labour, you can't fire'. ${ }^{16}$ One of the area's sugar estates, Uitvlugt, reported that for the first harvest in 2014, less than 50 per cent of the labour force turned up for work. ${ }^{17}$ The words of one senior manager at GUSYSUCO, the state Sugar company, ${ }^{18}$ who, in summing up the situation in the industry, resonate quite powerfully here: 'This morning, I read that gold price dropped GUY\$200-\$300, and I was like, God bless GUYSUCO, and I phoned another (manager) and I said, "Watch, people [labourers] will be back". 19

Why has there been such a struggle to retain unskilled labour? The broad consensus among interviewees is that in both the rice and sugar sectors, agricultural work is arduous, not particularly enjoyable and unappealing economically: that many people are moving into gold mining, which, though at times equally-unpleasant and challenging work, provides far greater economic returns. The estate managers interviewed seemed to sympathise with their labour force, and claimed to understand why low-skilled people would entertain a move to small- and medium-scale gold mining. As one estate manager explained in an interview, 'to come to work here, you wake up at four in the morning, be at work for six and be home at whatever time, so if they can find an alternative, so they are at work at seven, not in the rain, they'll do it'. ${ }^{20}$ Another, despite expressing frustration over what was described as an 'acute shortage' of labour, explained that 'so we realise that no one wants to cut [sugar] cane'. 21

But the problem extends to skilled labour, which is even more difficult to replace. All of the rice and sugar estate managers interviewed expressed frustration over not being able to find enough excavator operators and machine repairmen. The problem is particularly serious for GUYSUCO management, which expends considerable resources educating individuals with the knowledge that they may not stay with the company. With a reputation of producing high-quality skilled personnel, GUYSUCO has been heavily victimised by industry 'poaching', its management long, and perhaps naïvely, assuming that an assortment of employee benefits are sufficient to discourage people from pursuing better-paid work, such as that offered by small- and medium-scale mining. One manager acknowledged as much in an interview, explaining that 'What we would pay a labourer here, the private sector would pay three times even though GUYSUCO provide health care and pension but youngsters not interested in this ... [and that we are] struggling to pay an excavator here GUY\$1000/month, he goes to the bush and makes GUY\$5000/month'. ${ }^{22}$ Several estate managers provided very detailed stories which cast further light on the problem. One confessed that: 
When mining started, started to climb, more equipment was used, more excavators were used, and that pulled from us operators and tradesmen ... From 2010 to the end of June this year, we lost 67 operators (tractor and excavator) and we would have lost 40 tradesmen (mechanics of all levels), most went to mining ... We try and recruit and train but when you recruit, you don't know. Right now we have 13 people training to get the license but we don't know if they will stay $\ldots{ }^{23}$

A GUYSUCO manager echoed these sentiments, explaining that "when the gold price was US $\$ 1900$ an ounce, my executives came into my office, and said: the four artisans we trained who finished training last week have gone to the bush without serving a week but these guys get paid a fortune fixing a hydraulic line'. ${ }^{24}$ Overall, another estate manager professed: 'What mining has done is pull the skills for machinery'. ${ }^{25}$

Moreover, the gold boom has, perhaps predictably, through a 'resource movement effect', inflated costs elsewhere in the economy, which has impacted all citizens. The government officials and farmers interviewed all pointed to how fuel was scarce and costly at times because of its high demand in the interior for mining. The estate managers and farmers consulted expressed frustration over the lack of excavators, which many explained were being taken away from agriculture and reassigned, unannounced, to mining by machine leasing companies. These points were raised repeatedly during interviews with government officials. One remarked, perhaps exaggeratedly, that 'when people go for machinery, they are quoting the gold price' ${ }^{26}$ The same government official reflected on how the sudden mass movement of labour from agriculture to gold mining was affecting local costs and, in the process, making life very difficult for ordinary citizens:

... around November [2012], there was a huge demand for chicken, which we [Guyana] are selfsufficient in. But because of the huge demand in the interior, we nearly needed to import chicken. Because you pay GY\$400 in Georgetown, and the man in the bush will pay GY\$500. What do you think happens then?

The inflation has also brought about a 'spending effect', which occurs when resource booms increase prices in non-tradable sectors, causing an appreciation in the real exchange rate. This often leads to competiveness issues in sectors other than the 'booming' resource sector, in this case, mining. Although Guyana's nominal exchange rate with the United States depreciated in the range of 3.5 per cent between 2004 and 2013 (Central Bank of Guyana, 2014), increases in domestic prices of approximately 60 per cent over the same time period (Central Bank of Guyana, 2014), compared to increases in the United States of under 25 per cent (United States Bureau of Labour Statistics, 2014), have fuelled an appreciation in the real exchange rate by almost 24 per cent. This has affected sectors such as agriculture and manufacturing, further retarding growth and exacerbating the economy's reliance on gold.

This discussion has provided a glimpse of what could be considered a gold mining-induced 'resource movement effect' in Guyana. A second major 'symptom' of Guyana's resource curse, it has drawn resources away from agriculture and stifled the growth of sectors such as manufacturing in the process, making the country's economy even more one-dimensional.

\subsection{Weak Institutions, Elites and Local Development}

As is the case with many resource-rich developing countries, the problems documented here about Guyana are largely a result of weak institutions and governance. To recapitulate, the chief criticisms of countries dominated by large-scale, export-based gold mining economies is that operations tend to develop as enclaves; contribute minimally to local development; and make financial contributions which rarely reach the very communities affected by activities. The insinuation has been that the management of these companies, which are typically headquartered in Canada, Europe, South Africa, Australia or the United States, has very little interest in ensuring 
that finances escape the clutches of corrupt government officials. Is Guyana's rather unique gold mining industry, which is populated by local operators and financed by local investors, a viable blueprint for avoiding such an outcome?

Mahdavy's (1970) concept of the 'rentier state' applies here. A forward-thinking economist, Mahdavy (1970) reflected on how oil-rich Middle Eastern countries were rapidly spending oil riches which they did not earn as opposed to using them to develop other industries. This analysis has since become the foundation of the 'institutional strand' of the resource curse. Though perhaps not as extreme as in oil-rich states, Guyana, with its institutions doused in revenues from gold mining, is also showing signs of the 'rentier' behaviour. The country's institutions have similarly failed to 'cultivate an ethic of hard work', electing rather to 'follow an easy path to quick riches, spending money which they have not earned' (Yates, 2014, p. 96). It could be said that its 'sloth', as Sachs and Warner (1995) so eloquently put it, is reflected by what seems to be the government's inability to use its gold revenue productively, specifically to avert Dutch Disease and to develop the territories where gold mining takes place. Significantly, what the Guyana case does show is that even where there is an extractive industries blueprint in place which reserves mining for local participants, problems will ultimately arise if resource curse-type concerns are not adequately addressed up front in policy.

Guyana's 'sloth' has most recently manifested as inaction and neglect. On the one hand, the government is profiting handsomely from gold mining, collected monies from miners, who, by law, are required to sell all refined gold to the Guyana Gold Board, on which they must pay a 2 per cent tax and 5 per cent royalty. In 2013, earnings through these channels amounted to over US $\$ 40$ million for the more than $450,000 \mathrm{oz}$ of declared production (Figure 5). As both production and prices have risen, so, too, have projected revenues earned from mining: as Figure 5 indicates, the government earned considerable revenue during the gold boom. ${ }^{27}$ In fact, the rate of increase in gold mine revenue has been so rapid that it has risen to levels that compare, and most probably exceed, the potential Reducing Emissions from Deforestation and Forest Degradation (REDD+) payments received under the country's agreement with Norway. ${ }^{28}$

On the other hand, these gains have been heavily overshadowed by the government's inactions, specifically, its failure to act promptly to minimise losses of mine revenue, and the lack of attention it has paid to reinvesting profits in gold-producing regions. In the case of the former, it is smuggling which is the main concern. Neighbouring Suriname, which charges only a 1 per cent tax and 2 per cent royalty on gold, is the main destination for most smuggled product. Porous borders, the logistical challenges with monitoring the numerous locations in Guyana's interior where mining takes place, and

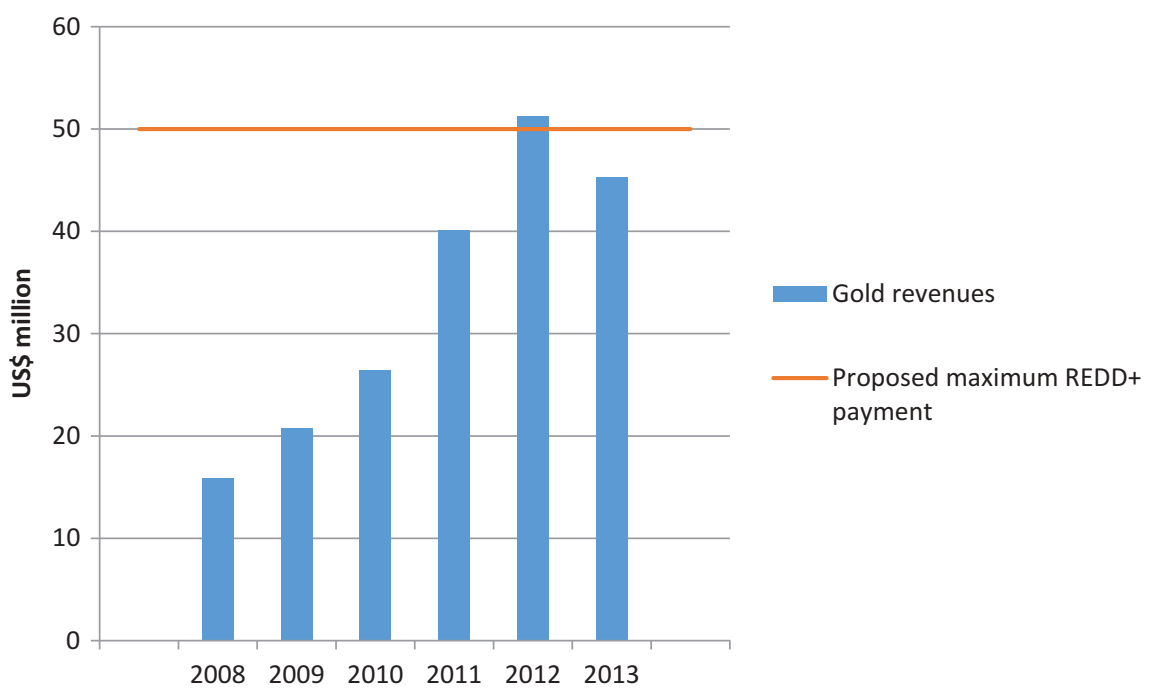

Figure 5. Gold public revenues and proposed maximum Low Carbon Development Strategy payment. 
the requirement to sell all gold to the Guyana Gold Board, has fuelled rampant smuggling. ${ }^{29}$ Gold smuggling has been projected to be as much as 35 per cent of total declared production ${ }^{30}$ with potential lost government revenue to the tune of US\$14 million estimated for the first five months of 2014 alone. ${ }^{31}$ Smuggling, however, likely extends to many other areas of the Caribbean and Latin America, as recent events in Curacao suggest: here, in 2012, Guyanese gold valued at US\$11.5 million was seized, ${ }^{32}$ reinforcing concerns that a gold smuggling ring has existed between the two countries for the last 15 years. ${ }^{33}$ Under previous governments, there was no great sense of urgency to address the gold smuggling problem, the lack of initiative at the policymaking level a sign that the authorities were content with the large sums they were already pocketing. However, with a change of government in 2015 coupled with a drop-off in international gold prices, leading to falls in revenues, a major campaign against large-scale smuggling rings was initiated. ${ }^{34}$

This leads to the latter point - that despite what national budgets may suggest, revenues earned from gold are not being reinvested in mining communities. Visits to Mahdia, one of Guyana's major smalland medium-scale gold mining towns, reinforced these suspicions. Located in the Potaro Mining District (Mining District 2) of Region 8 of the country and accessible from Georgetown via air or an arduous 10-hour road journey, Mahdia, with its population of 2000-3000 people, has developed on the back of the fortunes of gold mining. As with most 'boom towns', it is laced with numerous 'mining services', including countless eateries and bars, hotels, brothels and video houses. But at the same time, local livestock, agricultural and forestry industries have failed to grow, and are certainly in no position to sustain local demand. Most who have tried to 'branch out' into these and allied industries have struggled mightily due to poor infrastructure and a lack of government support. As one miner explained in an interview, 'In 1997, [I] came to Mahdia ... opened a meat centre, a shop, for nine years, stopped, had abattoir, live chickens, cows, fish ... [but] road got bad, cows got injured, break neck, so had to stop because we started to lose'. ${ }^{35}$ With no foundation for such staple industries, provisions are therefore shipped in from Georgetown and sold at inflated prices (Lowe, 2006).

Several interviewees reflected on the current situation in Mahdia. One local government official was particularly vocal about its lack of development and what he believed to be the government's neglect of the town, despite being the location of a vibrant gold mining industry:

The Government collected over 80,000 oz of gold from mining District 2 in Subregion 2, in 2012 ... as you can see, we have a problem in Mahdia where you can only give 12 hours of electricity a day because they claim they are not getting enough finance from it ... If you could build a 60 million Mahdia Hotel, you can build a technical institute to [train and] empower the people ... [The ruling] PPP (People's Progressive Party) man has a pickup truck to drive from home to work, about 300 feet but police don't even have a vehicle ... Only a moped (scooter), don't even have their own separate quarters. ${ }^{36}$

Several miners were also highly critical of the state of Mahdia, as captured by the following excerpts from interviews.

If we had better conditions with light and road, you could have a private school ... Current is important to diversify .... Infrastructure is very poor ... foundation is pretty weak for development ... ${ }^{37}$

People are already paying tax ... and the obligation for ruling people in this country is to get a current, to have road, water but there are so many cases that this is not happened. ${ }^{38}$

One of the problems is they don't have a bank here, and sometimes you have money, you can't even put it away. You have to transfer money out, use one of these money transfers, get someone to collect, and go... ${ }^{39}$ 
Government should pay a little attention to Mahdia ... a lot of things people need here ... look at the schools, the hospital, sick people survive but small people stay where they are. ${ }^{40}$

Residents seem to recognise that, in the words of one miner, 'road, building is not being developed' because 'all the gold and diamond being taken out'. ${ }^{41}$ Overall, Mahdia and other gold-producing localities in the country seem to be experiencing similar challenges to most towns affected by extraction and processing activities in countries which have pursued the large-scale export-based development path. These findings complement a sizable body of literature which captures in depth the social problems including prostitution and excessive violence - which plague such towns (see for example, Carrington, Hogg, \& McIntosh, 2011; Obeng-Odoom, 2014; Ruddel, Jayasundara, Mayzer, \& Heitkamp, 2014).

This leads to a final concern, which is that this 'sloth' has empowered a small group of wealthy elites, who now control the sector, under the umbrella industry organisation, the GGDMA: in 2013, 10 companies accounted for 30 per cent of the country's total declarations of gold production. The political and economic ramifications of this small concentration of power could be quite significant because, as Canterbury (2014) correctly points out: 'The small and medium-scale miners are becoming a powerful force in Guyana in the light of the fact that in the absence of any large-scale gold mining operation, the industry was second in foreign exchange importance after sugar' (p. 169). There is little disputing that having in place a galvanised and powerful small- and medium-scale sector controlled by influential residents could help to preserve a 'space' for locals as the country is opened to foreign investors.

But further empowering a small group of elites, a criticism often voiced about large-scale gold mine development and accompanying export-led growth, could have precisely the opposite effect. For example, how receptive would these individuals be toward a radical policy by government to emphasise the re-investment of mine revenues in towns such as Mahdia? Many of these operators seem to be profiting from the government's failure to do so, investing their own monies in construction services, and various businesses such as hotels and restaurants, profiting enormously in the process. An NGO officer reflected on the power which this small group of elite miners wield in an interview:

The miners close down Bartica. If you are able to close down Bartica, you have to be influential ... They [these miners] have politicians in their pocket ... They give [money] to parties on both sides. ${ }^{42}$

The mentioning here of Bartica, a bustling town which is the 'Gateway to the Interior' of Guyana, was reference to how, in February 2010, miners took to the street to protest against the government's proposed policy measures, to be taken under the auspices of the REDD+ agreement with Norway. Miners, visibly upset over the ideas presented, including allowing for a six-month notification period before activities can commence, physically closed the town, prompting immediate response from the government. ${ }^{43}$ Miners further revealed their growing influence in July 2012, when, following the announcement of the Ministry of Natural Resources and the Environment to suspend new river mining claims, in the span of a few days, managed to facilitate a change of course by the government. Officials quickly repealed the initial decision, clarifying that the suspension was merely temporary whilst a review was undertaken. Shortly after this announcement, the suspension was removed altogether. ${ }^{44}$ Given the political influence which local mining elites now have in Guyana, therefore, it would seem that it would be in the best interest of the government to appease these individuals - not a particularly enviable position to be in for an economy in desperate need of diversification.

To summarise, despite having an exceptionally unique gold mining sector, Guyana exhibits all of the symptoms which scholars associate with a 'resource curse'. Its extractive industries development model is, at least on paper, a blueprint which epitomises everything about local development. But having in place a strategy which puts local people at the core of economic development has failed to steer Guyana down a radically different development path to that of countries which have promoted large-scale, export-based mining. The Guyana case is a stark reminder of how similar outcomes can arise in very different extractive industries economies, regardless of the blueprint followed. 


\section{Conclusion: Critical Reflections on Guyana's Unique Resource Curse}

At the time of writing, Guyana was suffering immensely from a sudden decline in the gold price. The architect of a flourishing small- and medium-scale mining industry populated and controlled by its citizens, Guyana was well-positioned to diversify its economy using the earnings from a mining boom propelled by high gold prices. The broad consensus among policymakers interviewed in Georgetown was that the decision to pursue this model of extractives-led development was made because of a desire to ensure that revenue and ancillary benefits from mining remain in-country. Others believed it was Guyana challenging the predominant neoliberal model of extractive industries development large-scale, export-led growth driven by foreign multinationals - being implemented by the West and donors in most poor countries across Latin America, sub-Saharan Africa and Asia. What lessons can be learned from the Guyanese gold mining experience?

The first concerns governance. Whilst there is little disputing that Guyana now has in place a mining industry which is better-calibrated to make a lasting contribution to local development, its institutions seem built to rent-seek, and have therefore failed to lay the policy foundation needed to make this (local development) a reality. An alteration in the type of mining activity being undertaken, however radical it may be, is incapable of preventing the onset of a resource curse-type situation on its own. The key is the effective management of revenue. Policymakers must be genuinely committed to spending and managing appropriately, and must also make a concerted effort to avoid falling into the 'sloth' trap that typically follows a windfall. It appears that Guyana is failing on both fronts.

Second, the Guyana case has shown that even the smallest of resource booms is capable of drawing valuable financial and human capital from other sectors of the economy. For countries with so many glaring development needs, the failure to anticipate and adequately prepare for this could have crippling economic impacts in the medium to long-term. In Guyana, very little is being done to resuscitate its sugar industry, long the backbone of its economy. Although there are some efforts being made to identify new markets for rice, it is still an industry which faces an uncertain future, given the collapse of the fragile agreement with neighbouring Venezuela. Guyana serves as a timely reminder of the perilous position in which a developing country can quickly find itself if efforts are not made to protect and develop other industries during a resource boom.

Finally, what is being done to ensure that the industry in question does not come under the control of a small group of elites? The problem with the large-scale, export-led model is that it tends to do just this: privilege foreign companies and enrich host governments. In Guyana, the government has done an excellent job of bolstering its domestic small- and medium-scale gold mining economy, and simultaneously preventing foreign operators from seizing control of precious mineral reserves. But in doing so, it has further empowered the country's small- and medium-scale miners. Similar to the situation in so many developing world settings dominated by foreignfinanced, large-scale, resource extraction activities, Guyana's gold mining economy is now controlled by a small group of wealthy elites with strong political connections. Exhibiting 'rentier' behaviour on par with some of Africa's most corrupt oil states, the Government of Guyana seems to have ignored this very significant development, content with receiving taxes and royalties from operators. Allowing elites with political influence to flourish, in exchange for short-term rewards, in countries that are overly-dependent on resource extraction could stifle plans for development should they oppose the government's actions.

A uniquely-structured mining industry, which seems well-positioned to deliver significant locallevel benefits, has not enabled Guyana to escape what scholars would consider a resource curse. The case of Guyana is further affirmation that there are a number of reasons why resource-rich developing countries underperform economically.

\section{Acknowledgements}

The authors would like to thank Miss Diana Fernandes for her assistance with the fieldwork, $\mathrm{Mr}$ Rickford Vieira for facilitating access to the Mahdia GGMC office, and to all of the interviewees for 
putting aside time in their busy schedules to participate in the research. The authors would also like to thank two anonymous reviewers, who provided critical feedback on a previous draft. Financial support for this research was provided by the British Academy as part of a mid-career fellowship, 'Carbon Reduction and Forest-Based Livelihoods: A critical Overview of the REDD-Mining Debate in Guyana' (MD120008), and the Economic and Social Research Council (Grant ES/1O25154/1).

\section{Disclosure statement}

No potential conflict of interest was reported by the authors.

\section{Notes}

1. <http://www.mining.com/randgold-produces-record-results-with-14-more-gold-42555/> (Accessed 12 March 2015); <www. mineweb.com/mineweb/content/en/mineweb-gold-news?oid=176484\&sn=Detail $>$ (Accessed 14 May 2015).

2. <http://www.eurasianet.org/node/67372> (Accessed 15 June 2015).

3. The Extractive Industries Transparency Initiative (EITI) is an international intervention, coordinated by a multi-stakeholder board comprised of representatives from civil society, the private sector, governments and the donor community, which assesses the levels of transparency in the mining and oil and gas sectors. See $<$ https://eiti.org/ $>$ (Accessed 10 December 2014).

4. <http://www.reuters.com/article/2011/09/14/peru-mining-royalties-idUSS1E78C2AF20110914> (Accessed 12 December 2014).

5. <https://eiti.org/news/ghana-eiti-reports-revenue-oil-and-gas-first-time> (Accessed 12 December 2014).

6. For the purposes of anonymity, the names of the estates are not provided.

7. <http://guyanachronicle.com/guyana-records-highest-ever-gold-declaration/> (Accessed 2 January 2015).

8. Interview, Rice Farmer, Leguan Island, 29 July 2013.

9. Established in 2005, Petrocaribe is an alliance of Caribbean states with Venezuela. It was established to facilitate the purchasing of oil by the former from the latter on favourable terms. See $<$ http://www.petrocaribe.org $>$ (Accessed 14 November 2014).

10. <http://www.kaieteurnewsonline.com/2013/03/24/venezuela-is-a-lucrative-market-for-guyanas-rice/> (Accessed 11 December 2014).

11. <http://www.caribnewsdesk.com/news/8973-imf-concerned-about-impact-of-petrocaribe-s-likely-collapse-on-caribbean> (Accessed 11 December 2014)

12. Interview, Government Official, Georgetown, 21 July 2013.

13. Interview, Estate manager 1, Demerara, 29 July 2013.

14. Interview, Estate manager, Berbice, 30 July 2014.

15. Interview, Estate manager 2, Demerara, 29 July 2013.

16. Interview, Estate manager 3, Demerara, 29 July 2013.

17. <http://www.guyanatimesgy.com/2014/09/04/new-GuySuCo-board-begins-review-of-strategic-plan/> (Accessed 11 December 2014).

18. GuySuCo is the government-owned Guyana Sugar Corporation, and the country's largest producer of sugar.

19. Interview, GuySuCo manager, 29 July 2013.

20. Interview, Estate manager 2, Demerara, 29 July 2013.

21. Interview, Estate manager, Berbice, 30 July 2014.

22. Interview, GuySuCo manager, 29 July 2013.

23. Interview, Estate manager 2, Demerara, 29 July 2013.

24. Interview, GuySuCo manager, 29 July 2013.

25. Interview, Estate manager 3, Demerara, 29 July 2014

26. Interview, Government official, Georgetown, 21 July 2013.

27. As calculated by declarations multiplied by average gold price for the year in question, multiplied by the 7 per cent royalty rate. These figures exclude a range of indirect taxes on mining.

28. Guyana has in place one of the most comprehensive REDD+ programmes implemented to date, an agreement between it and the Government of Norway. It is the centrepiece of Guyana's Low Carbon Development Strategy (LCDS), under which the country will receive, during the period 2010-2015, US\$250 million from Norway if it manages to protect 16 million ha of rainforest.

29. <http://www.stabroeknews.com/2012/archives/05/17/suriname-acknowledges-gold-being-smuggled-from-guyana/> (Accessed 11 December 2014).

30. <http://www.stabroeknews.com/2011/archives/05/06/joe-singh-worried-over-gold-smuggling/> (Accessed 11 December 2014). 
31. <http://www.kaieteurnewsonline.com/2014/06/11/gold-dealer-fingered-in-major-smuggling-racket-to-suriname/> (Accessed 11 December 2014).

32. <http://www.kaieteurnewsonline.com/2012/12/01/brazen-heist-in-curacaocuracao-police-snatch-us11-5m-in-gold-smuggledfrom-guyana/> (Accessed 11 December 2014).

33. <http://www.stabroeknews.com/2013/news/stories/02/03/us-asks-curacao-to-probe-gold-smuggling-2/> (Accessed 11 December 2014).

34. <http://www.stabroeknews.com/2015/news/stories/08/27/govt-cracking-down-on-rampant-gold-smuggling-trotman/> (Accessed 21 September 2015).

35. Interview, Miner 1, Mahdia, 6 April 2013.

36. Interview, Government Official, Mahdia Government official, 2 April 2013.

37. Interview, Miner 1, Mahdia, 6 April 2013.

38. Interview, Miner 2, Mahdia 7 April 2013

39. Interview, Miner 3, Mahdia, 7 April 2013.

40. Interview, Miner 4, Mahdia, 8 April 2013.

41. Interview, Miner 5, Mahdia, 25 April 2013.

42. Interview, NGO officer, Georgetown, 29 July 2013

43. <http://www.stabroeknews.com/2010/archives/01/30/gov\%E2\%80\%99t-scrambles-to-quell-bartica-protest/> (Accessed 11 December 2014).

44. <http://www.guyanatimesinternational.com/?p=18458>; <http://www.kaieteurnewsonline.com/2012/07/08/halt-to-newriver-mining-licences $\% \mathrm{E} 2 \% 80 \% \mathrm{~A} 6$ severe-threats-to-livelihoods-environment-prompted-decision-govt/>;

$<$ http://www.kaieteurnewsonline.com/2012/07/11/suspension-of-new-river-mining-licences\%E2\%80\%A6-miners-supportno-confidence-vote-in-minister/>;

$<$ http://www.stabroeknews.com/2012/news/stories/07/12/one-month-halt-to-river-claims-ggmc/>; <htttp://www.stabroe knews.com/2012/news/stories/09/02/miners-force-authorities-to-step-back-on-proposed-regulations/> (All accessed 11 December, 2014).

\section{References}

Ackah-Baidoo, A. (2012). Enclave development and 'offshore corporate social responsibility': Implications for oil-rich subSaharan Africa. Resources Policy, 37(2), 152-159. doi:10.1016/j.resourpol.2011.12.010

Ahmadov, A. K. (2014). Oil, democracy, and context: A meta-analysis. Comparative Political Studies, 47, $1238-1267$. doi: $10.1177 / 0010414013495358$

Amundsen, I. (2014). Drowning in oil: Angola's institutions and the "resource curse". Comparative Politics, 46, $169-189$. doi: $10.5129 / 001041514809387333$

Auty, R. M. (1991). Managing mineral dependence: Papua New Guinea 1972-89. Natural Resources Forum, 15(2), 90-99.

Auty, R. (1993). Sustaining development in mineral economies: The resource curse thesis. London: Routledge.

Avalos, N., Gonzales, V., Stuva, A. H., Lida, K., \& Okazoe, N. (2013). Papua New Guinea and the natural resource curse (Working Paper No. 128). Bangkok: United Nations Economic and Social Commission for the Asia and the Pacific.

Bergh, A., Mirkina, I., \& Nilsson, T. (2014). Globalization and institutional quality - A panel analysis. Comparative Political Analysis, 47, 365-394. doi:10.1080/13600818.2014.884555

Bloch, R., \& Owusu, G. (2012). Linkages in Ghana's gold mining industry: Challenging the enclave thesis. Resources Policy, 37 (4), 434-442. doi:10.1016/j.resourpol.2012.06.004

Brahmbhatt, M., Canuto, O., \& Vostroknutova, E. (2010). Dealing with dutch disease. Washington, DC: World Bank.

Bräutigam, D. (2008). Taxation and governance in Africa: Take a second look. Washington, DC: American Enterprise Institute for Public Policy Research.

Canterbury, D. (2014). Extractive capitalism and the resistance in Guyana. In J. Petras \& H. Veltmeyer (Eds.), Extractive imperialism in the Americas: Capitalism's new frontier (pp. 147-175). Amsterdam, The Netherlands: Brill.

Carrington, K., Hogg, R., \& McIntosh, A. (2011). The resource boom's underbelly: Criminological impacts of mining development. Australian \& New Zealand Journal of Criminology, 44, 335-354. doi:10.1177/0004865811419068

Carrington, W. J., \& Detragiache, E. (1999). How extensive is the brain drain? Finance and Development, 36, 46-49.

Central Bank of Guyana. (2014). Quarterly report and statistical bulletin, Q1 Vol. 8 No. 1. Georgetown: Central Bank of Guyana.

Corden, W. M. (1984). Booming sector and dutch disease economics: Survey and consolidation. Oxford Economic Papers, 36 , 359-380.

Da Costa, M. (2007). Colonial origins, institutions and economic performance in the Caribbean: Guyana and Barbados (IMF Working Paper No. WP/07/43). Washington, DC: International Monetary Fund.

Economic Commission for Latin America and the Caribbean (ECLAC). (2014). Economic survey of Latin America and the Caribbean, 2014: Challenges to sustainable growth. Santiago, Chile: Economic Commission for Latin America and the Caribbean.

Ferguson, J. (2005). Seeing like an oil company: Space, security, and global capital in neoliberal Africa. American Anthropologist, 107, 377-382. doi:10.1525/aa.2005.107.3.377 
Ferguson, J. (2006). Global shadows: Africa in the neoliberal world order. Durham: Duke University Press.

Germany Trade and Invest. (2013). Guyana. Bonn: Germany Trade and Invest.

GGMC. (2009). Annual report. Georgetown: Guyana Geology and Mines Commission.

GGMC. (2010). Annual report. Georgetown: Guyana Geology and Mines Commission.

GGMC. (2011). Annual report. Georgetown: Guyana Geology and Mines Commission.

Gould, J. A., \& Winters, M. S. (2007). An obsolescing bargain in chad: Shifts in leverage between the government and the World Bank. Business and Politics, 9, 1-36. doi:10.2202/1469-3569.11.99

Guyana Bureau of Statistics. (2014). Statistical bulletin. Georgetown: Guyana Bureau of Statistics.

Heinrich, A. (2011). Challenges of a resource boom: Review of the literature (Working Paper No. 114). Bremen: Research Centre for East European Studies, University of Bremen.

Hennessy, L. (2015). Where there is no company: Indigenous peoples, sustainability and the challenges of mid-stream mining reforms in Guyana's small-scale gold sector. New Political Economy, 20, 126-153. doi:10.1080/13563467.2014.914158

Hilson, G., \& Maconachie, R. (2009). "Good governance" and the extractive industries in Sub-Saharan Africa. Mineral Processing and Extractive Metallurgy Review, 30, 52-100. doi:10.1080/08827500802045511

Hirschman, A. (1958). The strategy of economic development. New Haven: Yale University Press.

Jacome, F. (2011). Petrocaribe: The current phase of Venezuela's oil diplomacy in the Caribbean. Bogota: Programa de Cooperacion en Seguridad Regional, Friedrich Ebert Stiftung.

Karl, T. L. (1997). The paradox of plenty: Oil booms and petro-states. Berkeley: University of California Press.

Lane, P. R., \& Tornell, A. (1996). Power, growth and the voracity effect. Journal of Economic Growth, 1, 213-241. doi:10.1007/ BF00138863

Lowe, S. (2006). Situation analysis of the small-scale gold mining sector in Guyana. Paramaribo: World Wildlife Fund for Nature.

Mahadevan, R., \& Asafu-Adjaye, J. (2013). Exploiting comparative advantage in agriculture and resources: The way forward for Small Island States. Australian Journal of Agricultural and Resource Economics, 57, 320-343. doi:10.1111/j.14678489.2012.00618.x

Mahdavy, H. (1970). The patterns and problems of economic development in rentier states: The case of Iran. In M. A. Cook (Ed.), Studies in the economic history of the Middle East (pp. 37-61). London: Oxford University Press.

Mähler, A. (2011). Oil in Venezuela: Triggering conflicts or ensuring stability? A historical comparative analysis. Politics \& Policy, 39, 583-611. doi:10.1111/j.1747-1346.2011.00305.x

Mazzuca, S. L. (2013). The rise of rentier populism. Journal of Democracy, 24(2), 108-122. doi:10.1353/jod.2013.0034

Moran, T. H. (2013). Avoiding the "resource curse" in Mongolia. Washington, DC: Peterson Institute for International Economics.

Morris, M., Kaplinsky, R., \& Kaplan, D. (2012). "One thing leads to another"-Commodities, linkages and industrial development. Resources Policy, 37(4), 408-416. doi:10.1016/j.resourpol.2012.06.008

Moss, T. (2011). Oil to cash: Fighting the resource curse through cash transfers (Center for Global Development Working Paper No. 237). Washington, DC: Center for Global Development.

Obeng-Odoom, F. (2014). Oil, sex, and temporary migration: The case of Vienna City, Sekondi-Takoradi, Ghana. The Extractive Industries and Society, 1, 69-74. doi:10.1016/j.exis.2013.12.003

Ovadia, J. S. (2014). Local content and natural resource governance: The cases of Angola and Nigeria. The Extractive Industries and Society, 1, 137-146. doi:10.1016/j.exis.2014.08.002

Potter, L. (1998). Breaking away from sugar? East Indians and the rice industry of Guyana, 1905-1940. South Asia: Journal of South Asian Studies, 21, 137-160. doi:10.1080/00856409808723353

Prebisch, R. (1950). The economic development of Latin America and its principal problems. New York, NY: United Nations Economic Commission for Latin America.

Richardson-Ngwenya, P. (2013). Situated knowledge and the EU sugar reform: A Caribbean life history. Area, 45, $188-197$. doi:10.1111/area.12011

Ross, M. (1999). The political economy of the resource curse. World Politics, 51, 297-322. doi:10.1017/S0043887100008200

Ross, M. (2001). Does oil hinder democracy? World Politics, 53, 325-361. doi:10.1353/wp.2001.0011

Ross, M. (2014). What have we learned about the resource curse? (Working Paper). Los Angeles: University of California Los Angeles.

Rosser, A. (2006). The political eonomy of the resource curse: A literature survey (IDS Working Paper No. 268). Brighton: Institute for Development Studies.

Ruddell, R., Jayasundara, D. S., Mayzer, R., \& Heitkamp, T. (2014). Drilling down: An examination of the boom-crime relationship in resource-based boom counties. Western Criminology Review, 15(1), 3-17.

Sachs, J. D., \& Warner, A. (1995). Natural resource abundance and economic growth (National Bureau for Economic Research (NBER) Working Paper No. 5398). Cambridge, MA: National Bureau for Economic Research.

Saka, L., \& Sani, M. A. B. M. (2012). Resource rent and governance crisis in Gulf of Guinea oil states: The case of Angola. The Social Sciences, 7, 321-331. doi:10.3923/sscience.2012.321.331

Sala-i-Martin, X., \& Subramanian, A. (2013). Addressing the natural resource curse: An illustration from Nigeria. Journal of African Economies, 22, 570-615. doi:10.1093/jae/ejs033

San, A. A. A. (2014). Transparency in the Nigerian oil and gas industry. Journal of World Energy Law and Business, 7, $220-235$. doi:10.1093/jwelb/jwu012 
Shaxson, N. (2009). Angola's homegrown answers to the "resource curse". In J. Lesourne \& W. C. Ramsay (Eds.), Governance of oil in Africa: Unfinished business (pp. 51-102). Paris: Governance Europeenne et Geopolitique de L'Energie Tome 6.

Singer, H. W. (1950). The distribution of gains between investing and borrowing countries. American Economic Review, 40, 473-485. doi:10.2307/1818065

Singh, D., Bernard, C., Rampersaud, P., Laing, T., Priester, M., Hentschel, T., ... Watson, L. C. (2013). Guyana's extractive industry sector (EIS): A synopsis of issues and recommendations for the mining sector as a sustainable element of Guyana's low carbon development strategy (LCDS). Georgetown: Conservation International.

Staritz, C., Gold, J., \& Atoyan, R. (2007). Guyana: Why has growth stopped? An empirical study on the stagnation of economic growth (IMF Working Paper No. 07/86). Washington, DC: International Monetary Fund.

United States Department of Homeland Security. (2009). Yearbook of immigration statistics. Washington, DC: United States Department for Homeland Security.

United States Department of Homeland Security. (2012). Yearbook of immigration statistics. Washington, DC: United States Department for Homeland Security.

United States Bureau of Labour Statistics. (2014). Consumer Price Index. Retrieved January 5, 2015, from www.bls.gov/cpi/ \#tables

US Rice Producers Association. (2011). The rice advocate, Volume 10, Issue 11. Houston: US Rice Producers Association.

USAID. (2010). USAID country profile property rights and resource governance: Mongolia - Land tenure and property rights profile. Washington, DC: USAID.

World Bank. (2009). Economy-wide impact of oil discovery in Ghana (Report No. 47321-GH). Washington, DC: World Bank. World Bank. (2013). Local content policies in the oil and gas sector. Washington, DC: World Bank.

Yates, D. (2014). The rise and fall of oil-rentier states. In J. A. Grant (Ed.), New approaches to the governance of natural resources: Insights from Africa (pp. 92-127). London: Palgrave. 